University of South Florida

DIGITAL COMMONS

Digital Commons @ University of

@ UNIVERSITY OF SOUTH FLORIDA

South Florida

$1-1-2015$

\title{
2015 Accountability Report USF Sarasota-Manatee
}

USF

Follow this and additional works at: https://digitalcommons.usf.edu/usf_accountability_reports

\section{Scholar Commons Citation}

USF, "2015 Accountability Report USF Sarasota-Manatee" (2015). USF Accountability Reports. 49.

https://digitalcommons.usf.edu/usf_accountability_reports/49

This Article is brought to you for free and open access by the USF Archives at Digital Commons @ University of South Florida. It has been accepted for inclusion in USF Accountability Reports by an authorized administrator of Digital Commons @ University of South Florida. For more information, please contact digitalcommons@usf.edu. 


\section{4-15}

\section{Annual Accountability Report}

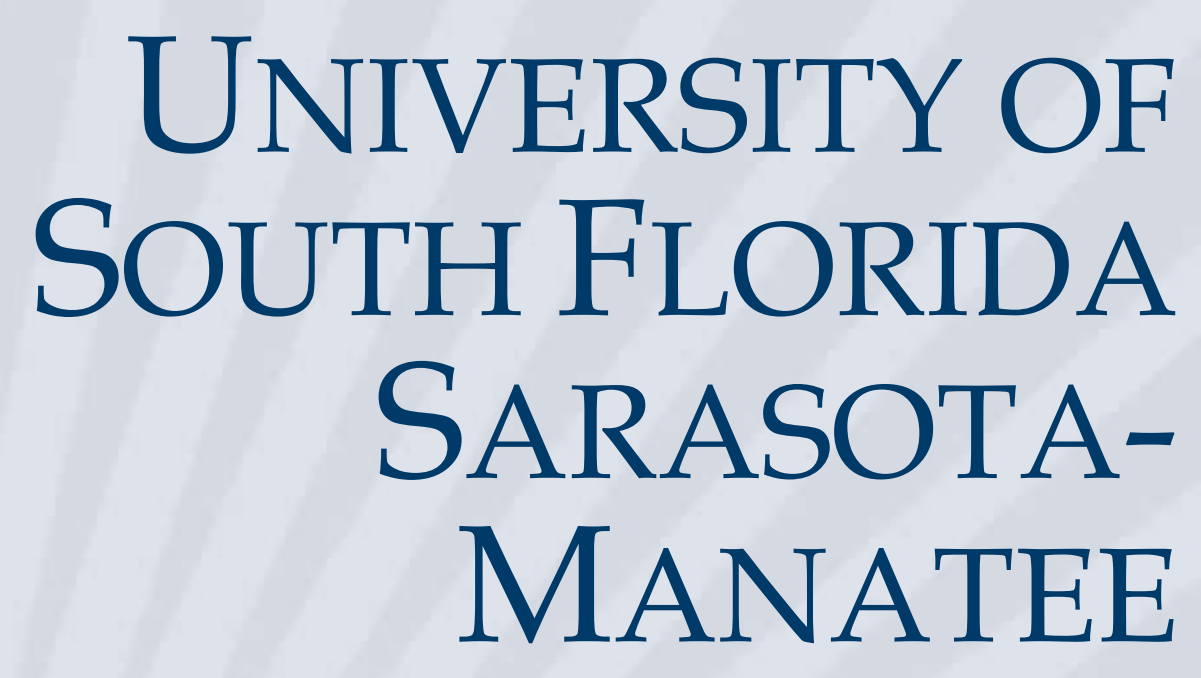

BOT APPROVED 3/3/2016

STATE UNIVERSITY SYSTEM of FLORIDA Board of Governors 


\section{TABLE OF CONTENTS}

\section{EXECUTIVE SUMMARY}

DASHBOARD

KEY ACHIEVEMENTS

NARRATIVE p. 2

p. 5

p. 6

\section{DATA TABLES}

SECTION 1. FINANCIAL RESOURCES p. 11

SECTION 2. PERSONNEL

p. 15

SECTION 3. ENROLLMENT

p. 16

SECTION 4. UNDERGRADUATE EDUCATION

p. 20

SECTION 5. GRADUATE EDUCATION

p. 28

SECTION 6. RESEARCH \& ECONOMIC DEVELOPMENT

p. 30 


\section{Dashboard}

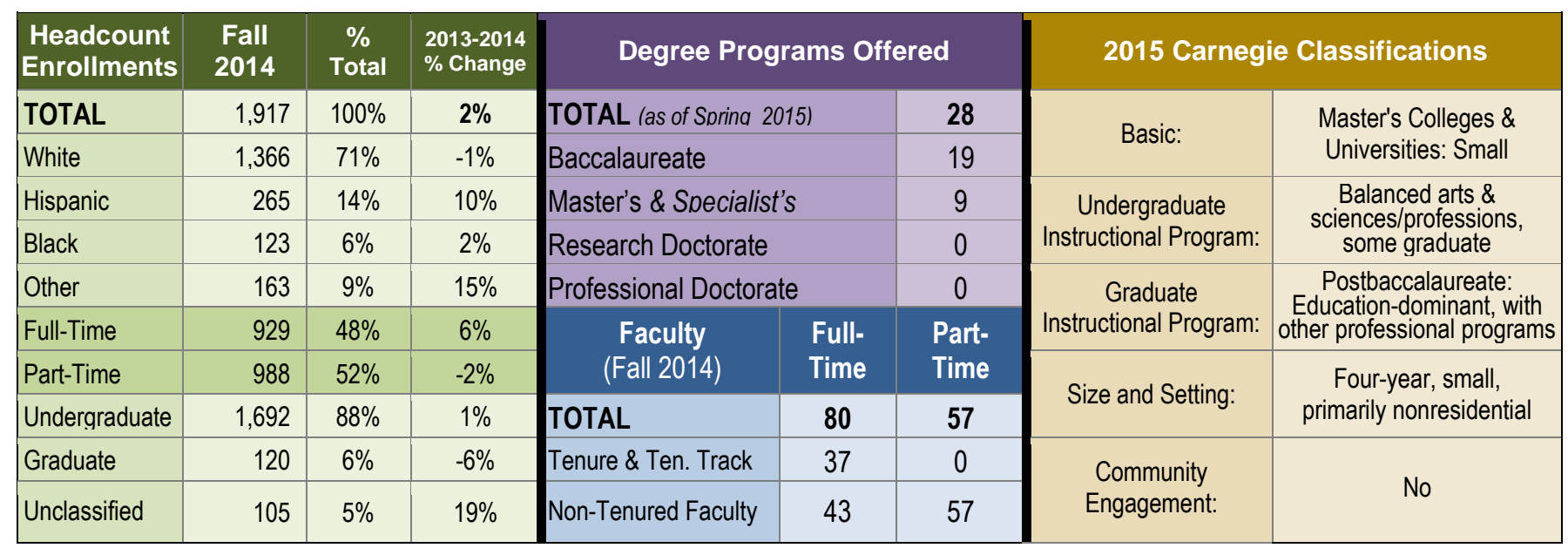

DEGREE PRODUCTIVITY AND PROGRAM EFFICIENCY
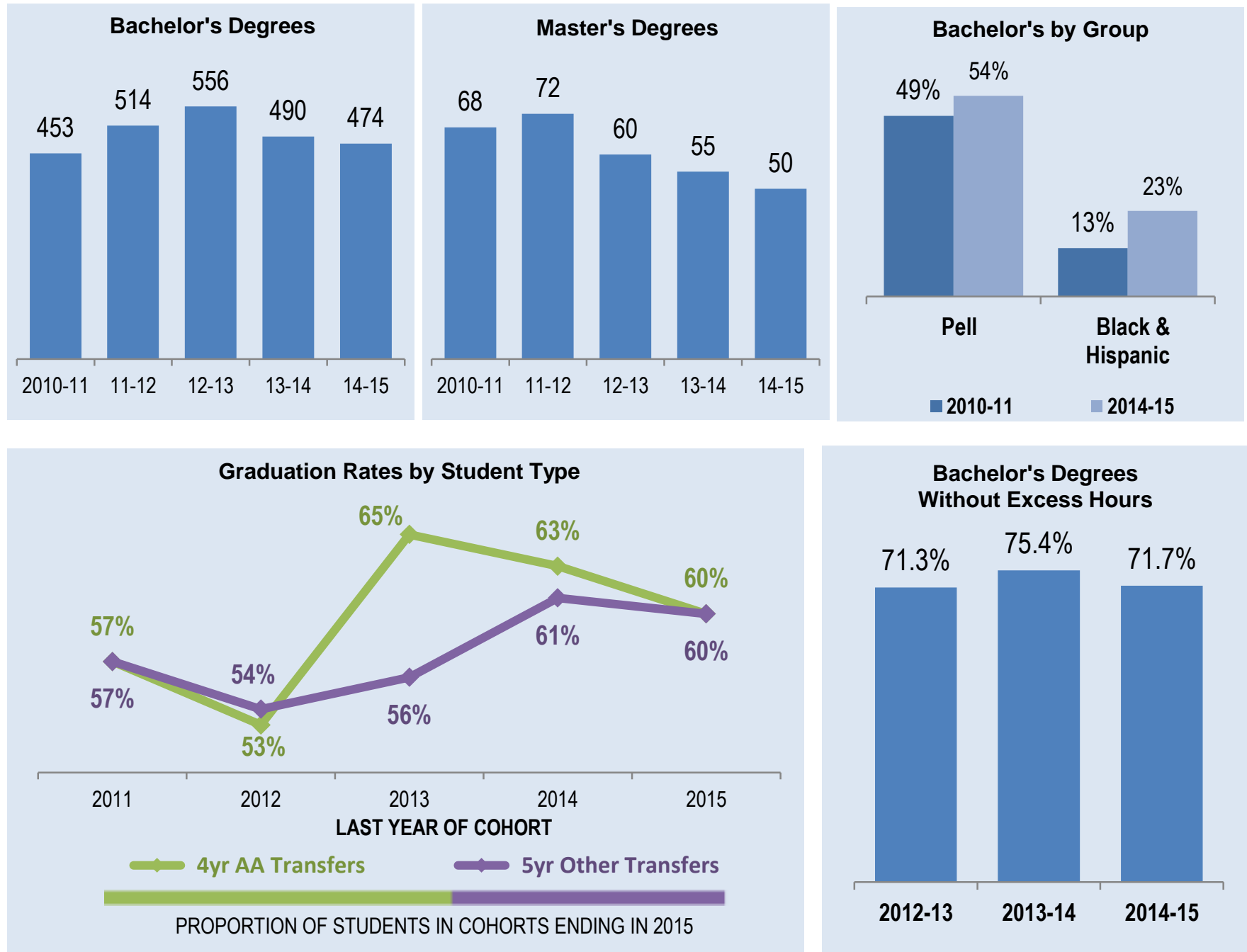


\section{Dashboard}

DEGREES AWARDED IN PROGRAMS OF STRATEGIC EMPHASIS (PSE)

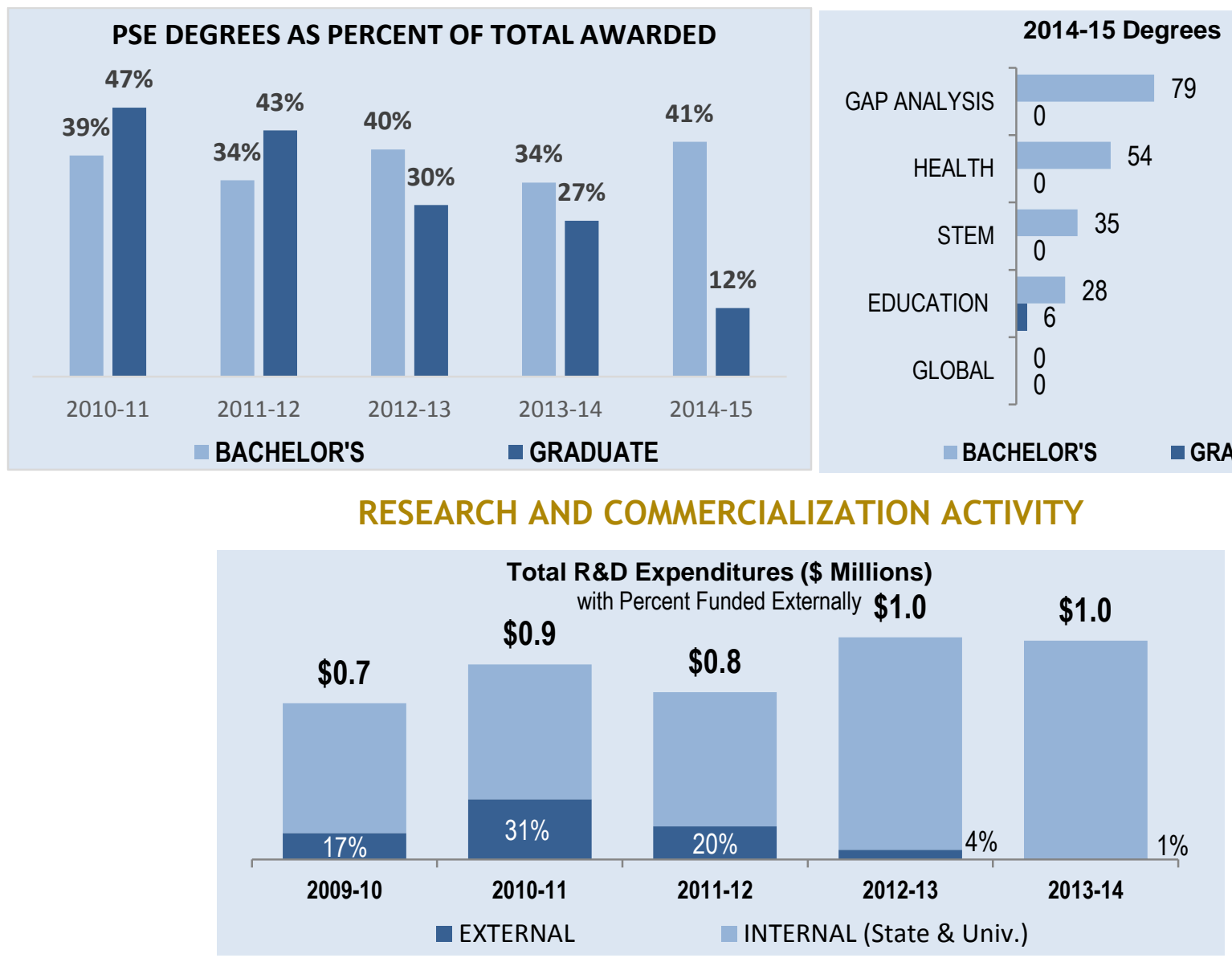

RESOURCES

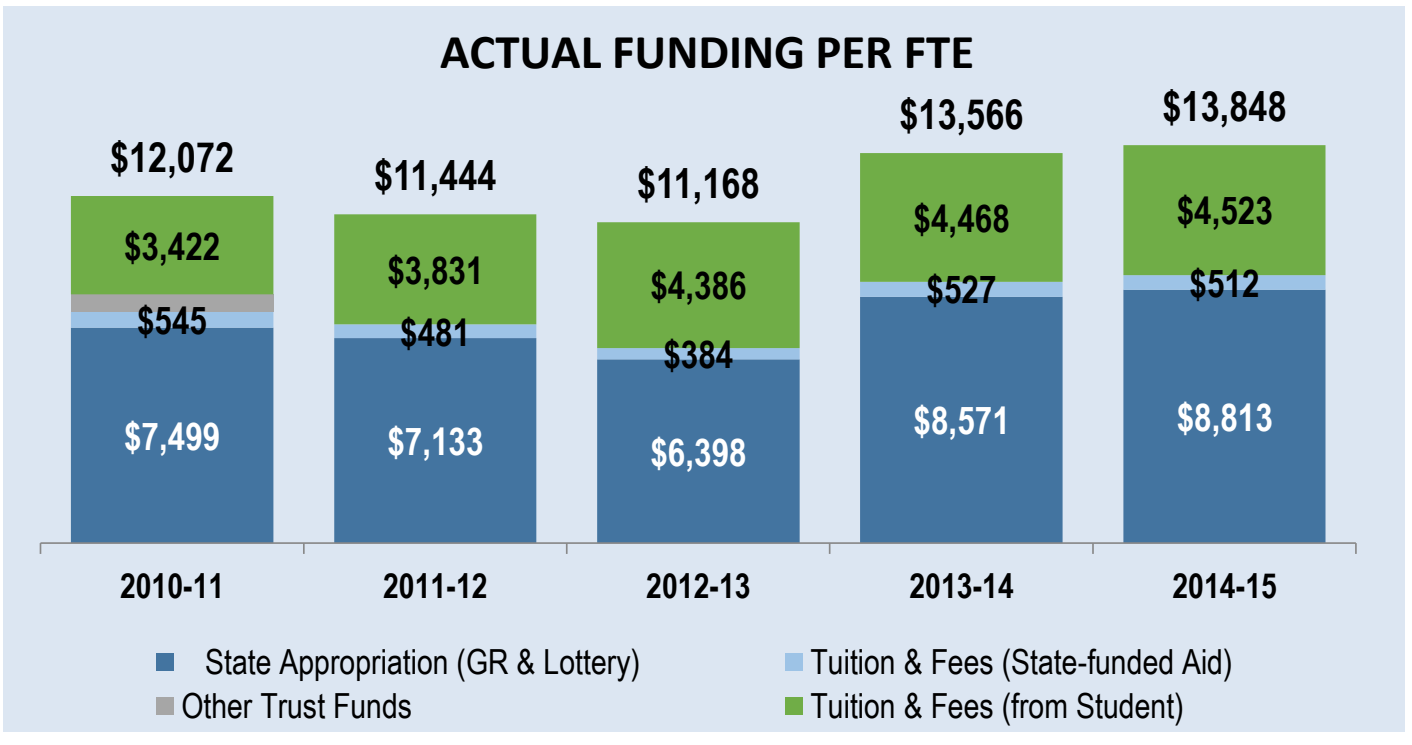




\section{Dashboard}

\section{POST-GRADUATION METRICS}

\section{Percent of Bachelor's Graduates Employed or Continuing their Education One Year After Graduation}

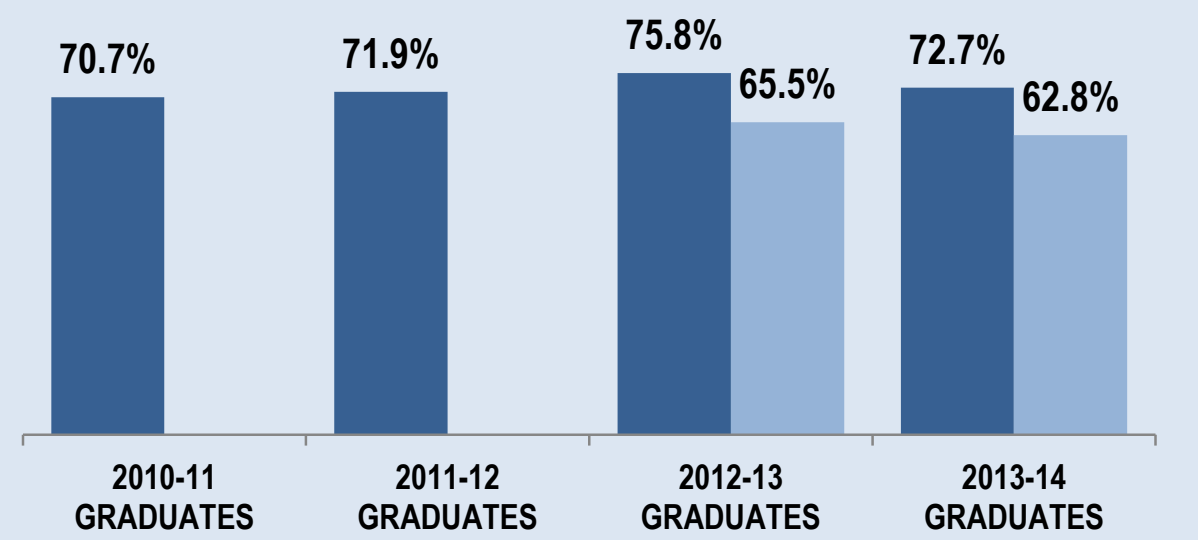

- Enrolled or Employed (Full-time) Enrolled or Employed (Earning \$25,000+)
Wages of Full-time Employed in Florida Baccalaureates One Year After Graduation 5th, 25th, 50th, 75th and 95th Percentiles

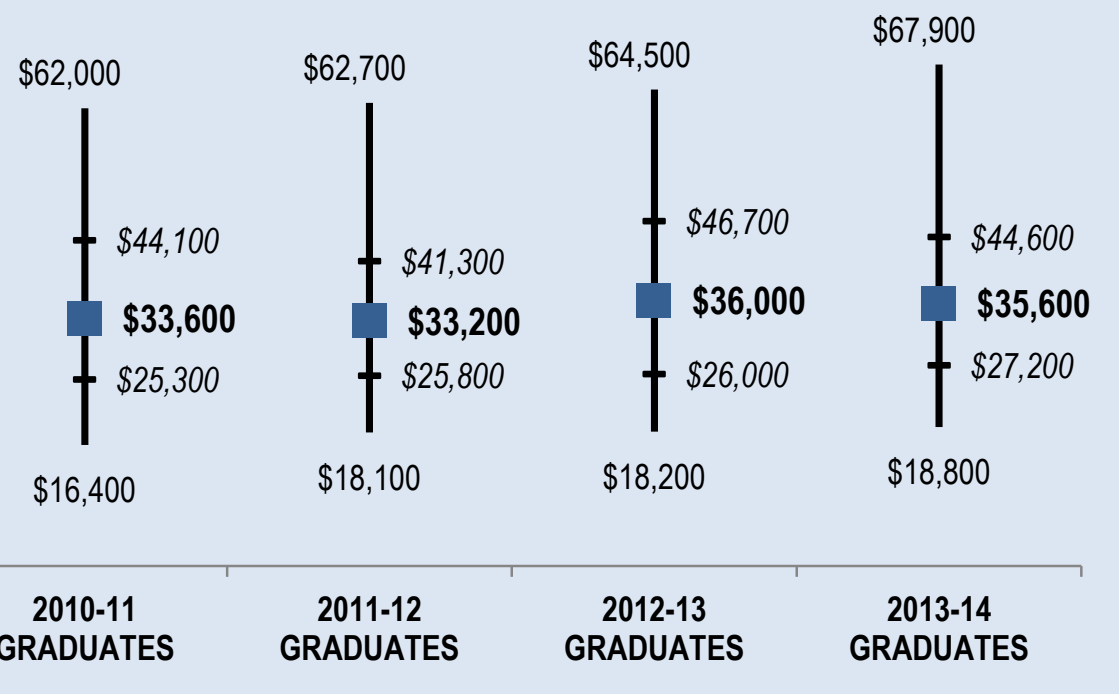

Notes: Percentages are based on the number of recent baccalaureate graduates who are either employed full-time or continuing their education in the U.S. (based on the National Student Clearinghouse data). Full-time employment is based on those who earned more than a full-time (40hrs a week) worker making minimum wage. Due to limitations in the data, the continuing enrollment data includes any enrollment the following year regardless of whether the enrollment was post-baccalaureate or not. Board of Governors staff found $89 \%$ of the total 2013-14 graduating class.

See Table 40 within this report for additional information about this metric.

Notes: Wage data is based on Florida's annualized Unemployment Insurance (UI) wage data for those graduates who earned more than a full-time employee making minimum wage in the fiscal quarter a full year after graduation. This Ul wage data does not include individuals who are self-employed, employed out of state, employed by the military or federal government, or those without a valid social security number. In 2013-14, these data accounted for $58 \%$ of the total graduating class. This wage data includes graduates who were employed full-time (regardless of their continuing enrollment). Wages are provided for 5th, 25th, 50th, 75th and 95th percentiles. Median wages are identified by bolded values. The interquartile range (shown in italics) represents $50 \%$ of the wage data. Wages rounded to nearest hundreds. 


\section{Key Achievements (2014-2015 academic year)}

Include achievements that were received/awarded during summer 2014, fall 2014, and spring 2015.

\section{STUDENT AWARDS/ACHIEVEMENTS}

1. The Campus Compact awarded USFSM student Jeanne Ashforth the Newman Civic Fellowship sponsored by the KPMG Foundation for her commitment to community and service.

2. Navy veteran and student Bryan Jacobs developed Vets-2-Chefs, a training program instructing veterans in the culinary arts.

\section{FACULTY AWARDS/ACHIEVMENTS}

1. Mathematics Professor Joy D'Andrea received the American Mathematical Society award for the Impact of Learning and Teaching Mathematics 2015.

2. History Professor Dr. June Benowitz published her book "Challenge and Change: Right-Wing Women, Grassroots Activism, and the Baby Boom Generation" (University Press of Florida).

3. Dr. Eric Hodges, Political Science Professor and Marine veteran, partnered with colleagues from Virginia Tech University in securing a \$150,000 grant from the National Endowment for the Humanities to develop a summer teaching institute around veterans' issues. Dr. Hodges will serve as a master teacher for the institute.

\section{PROGRAM AWARDS/ACHIEVEMENTS}

1. USF Sarasota-Manatee's Biology program received a $\$ 50,000$ grant from the Harry Sudakoff Foundation to support the construction of laboratory space on campus for independent faculty research in biology, biomedical sciences, and social science disciplines.

\section{RESEARCH AWARDS/ACHIEVEMENTS}

1. The Center for Partnerships in Arts-Integrated Teaching (PAInT) is supporting Project Elevate, a partnership with Sarasota County Schools and the Any Given Child Sarasota program, which includes the John F. Kennedy Center for the Performing Arts in Washington, D.C., and the Van Wezel Performing Arts Hall in Sarasota. USFSM faculty will evaluate the \$1.2 million Professional Development in Arts Education grant from the U.S. Department of Education for Sarasota County School District's Project Elevate.

2. Dr. Thomas Becker, Professor of Management, received two awards his paper: "Top 1\% (based on highly cited threshold) in the field of Economics \& Business" by the Social Science Citation Index Web of Science and one of the "Top 10 Most Noteworthy Manuscripts" by Organizational Research Methods.

3. Education Professor Dr. Jody McBrien was awarded the 2014 lan Axford (New Zealand) Fellowship in Public Policy, Coordinated by Fulbright New Zealand. Dr. McBrien collaborated with Immigration New Zealand in the Ministry of Business, Innovation, and Employment to evaluate new refugee resettlement policies. 


\section{Narrative}

\section{Teaching and Learning}

\section{STRENGTHEN QUALITY AND REPUTATION OF ACADEMIC PROGRAMS AND UNIVERSITIES}

USF Sarasota-Manatee continuously works to improve both the quality and reputation its academic programs. This past year USF Sarasota-Manatee made a concerted effort to increase its global recognition by partnering with USF World, based on the USF in Tampa campus, to increase international education opportunities. In 2014, USF Sarasota-Manatee received SACSCOC accreditation approval for its Hospitality and Tourism Leadership program to engage in student exchanges with five universities in Germany, Taiwan, Turkey, and France.

USF Sarasota-Manatee is improving its reputation by improving the students it attracts and enrolls. The USF Sarasota-Manatee Fall 2014 FTIC cohort showed an improved profile over its initial Fall 2013 FTIC cohort in average SAT scores (1.7\% increase), average high school grade-point average (5\% increase), and the percentage of students in the top $10 \%$ of their high school class (185\% increase).

\section{INCREASE DEGREE PRODUCTIVITY AND PROGRAM EFFICIENCY}

The following metrics evidence USF Sarasota-Manatee's continuous improvements in degree productivity and program efficiencies:

- Increased overall bachelor-degree production since $2010-11$ by $5 \%$.

- Increase in the percentage of bachelor's degrees awarded to Non-Hispanic Black students (5\% increase) and Hispanic students (3\% increase).

- More than 50\% of degrees awarded in 2014-15 were earned by Pell-grant recipients.

- Reflective of students' ability to access courses both on-campus and off, faculty delivered $49 \%$ of USF Sarasota-Manatee undergraduate FTE through distance learning courses.

- Master's-level students also increased their use of online courses, increasing the percentage of FTE earned through distance learning from $23 \%$ in $2013-14$ to $33 \%$ in $2014-15$.

\section{INCREASE THE NUMBER OF DEGREES AWARDED IN S.T.E.M. AND OTHER PROGRAMS OF STRATEGIC EMPHASIS}

Since attaining separate accreditation in 2011, USF Sarasota-Manatee has added four degree programs recognized by the Board of Governors as programs of Strategic Emphasis. The newest of these is the Bachelor of Science (B.S.) in Biology, which began enrolling students in Fall 2014. USF SarasotaManatee is partnering with Mote Marine Laboratories, a world-renowned marine science laboratory, to deliver the laboratory courses in Mote's facility. In just its first year of operation, the program has also secured $\$ 140,000$ in funding to open two modular laboratories on the USF Sarasota-Manatee campus for conducting faculty and undergraduate research experiments.

Attention to increasing the number and quality of degrees offered in the strategic areas has resulted in a five-year high in the percentage of total bachelor's degree awarded in Strategic Emphasis, 41\%. USF Sarasota-Manatee expects this percentage to increase after the spring of 2016, when the first cohort of upper-level Biology students begin graduating from the program. 


\title{
Narrative
}

\author{
Scholarship, Research and Innovation
}

STRENGTHEN QUALITY AND REPUTATION OF SCHOLARSHIP, RESEARCH AND INNOVATION

USF Sarasota-Manatee researchers and scholars made significant contributions to both inter- and intradisciplinary fields in 2014-15. To support their endeavors, USF Sarasota-Manatee appointed a Faculty Coordinator of Research in the spring of 2014. This position ensures that the institution leverages opportunities for cross-disciplinary research and actively develops and manages faculty needs and priorities for grants and other resources.

In addition to faculty research, USF Sarasota-Manatee promotes undergraduate and graduate student research through its annual Student Showcase for Projects, Research, \& Innovation. Beyond a research symposium, this annual event encourages students from across the institution to present works from action research projects to curriculum design to innovation projects. The Showcase is an excellent opportunity for students to not only present their work but also to learn from peers and to network with faculty.

\section{INCREASE RESEARCH AND COMMERCIALIZATION ACTIVITY}

USF Sarasota-Manatee faculty were hard at work in 2014-15 conducting research and innovating curriculum. For instance, John Stewart, Professional \& Technical Communications, created a virtual technical communications lab for online USF Sarasota-Manatee students. This laboratory successfully introduces students to the basics of XML authoring and other related high-end technology. The experience translated into national success when Professor Stewart was invited to present his paper "Implementing an XML Authoring Project in A new Media Course" at the IEEE International Professional Communication Conference at Carnegie Mellon University (October 2014).

Another USF Sarasota-Manatee professor, Dr. Aparna Telang, is working with undergraduate students to seek ways to control mosquito populations by studying pathogens inside the insects. A newly-built modular lab will house Dr. Telang's work as she seeks to identify a strain of symbiotic bacteria on which mosquitos depend and can be exploited to control their population levels. 


\section{INCREASE COLLABORATION AND EXTERNAL SUPPORT FOR RESEARCH ACTIVITY}

Most USF Sarasota-Manatee faculty members collaborate with non-profit and public organizations from across the Sarasota-Manatee region, including: the Sarasota and Manatee School Districts, Easter Seals, Jewish Federation, and Family Safety Alliance, to name just a few. These collaborative efforts provide opportunities for faculty to conduct research, assist non-profits and public entities, and provide opportunities for students to be involved in research activities, internships, and to identify and connect with local job opportunities.

In addition to their collaborative efforts, USF Sarasota-Manatee research activity has garnered the support of a number of external entities. For instance,

- The Partnerships for Arts Integrated Teaching (PAInT) Center is supported by grants and donations from individual and community donors.

- The Evelyn M. Duvall endowment funds the Duvall Family Studies Conference, which facilitates collaborations among university researchers and community practitioners who can utilize family studies research findings.

- The M3 Center for Hospitality Technology and Innovation is funded by the McKibbon Hotel Management Group providing for an Endowed Chair, graduate assistants for the College of Hospitality and Tourism Leadership, and faculty participation in national and international conferences.

\section{Community and Business Engagement}

\section{STRENGTHEN QUALITY AND REPUTATION OF COMMITMENT TO COMMUNITY AND BUSINESS ENGAGEMENT}

As part of the 2015-2020 Strategic Plan, "Focus on Quality," developed by faculty and staff in the spring of 2015, USF Sarasota-Manatee formed a plan to build a campus-wide infrastructure to support community engagement. Efforts are under way with the establishment of the Office of Community Engagement and the hiring of a Faculty Coordinator of Community Engagement. The Office is charged with cultivating strategic partnerships with government entities, service clubs, and community organizations.

\section{INCREASE LEVELS OF COMMUNITY AND BUSINESS ENGAGEMENT}

USF Sarasota-Manatee's vision is to "be nationally recognized as a student-centered, research focused, community-engaged university with significant economic and cultural impact to the region." An example of efforts toward achieving the vision are already under way. Dr. Marie Byrd, Dr. Helene Robinson, Dr. Brianne Reck, and Dr. Pat Wilson of the College of Education and the Center for Partnerships in ArtsIntegrated Teaching (PAInT) collaborated with Manatee School District's Early Learning Program and G. D. Rogers Garden Elementary School's principal to design a professional development program. The program was awarded a grant for implementation by the Manatee Community Foundation. 


\section{Narrative}

\section{INCREASE COMMUNITY AND BUSINESS WORKFORCE}

USF Sarasota-Manatee faculty seek opportunities to build capacity in the workforce beyond their classrooms. For instance, Dr. Jean Kabongo, associate professor of strategic management and entrepreneurship, conducted an entrepreneur workshop at a local community complex for current and aspiring entrepreneurs. The workshop, which is free and open to the public, stresses innovation and creativity in the marketplace.

USF Sarasota-Manatee also believes that building capacity within the workforce starts with area schools and youth. This is exemplified by the work of Drs. Marie Byrd and Pat Wilson of the College of Education and Center for Partnerships in Arts-Integrated Teaching (PAInT) collaborated with United Way Suncoast and Booker Middle School (Sarasota County Schools) to implement the Summer Arts-Integrated Literacy (SAIL) program. Teacher education candidates successfully tutored children at risk for summer reading achievement loss - none of the children regressed and most showed achievement gains in assessment results. The more these students succeed early in the life the greater chance they have to excel throughout their lifetimes. 


\section{Data Tables}

\section{FINANCIAL RESOURCES}

Table 1A. Education and General Revenues

Table 1B. Education and General Expenditures

Table 1C. Funding per Student FTE

Table 1D. Cost per Degree [New]

Table 1E. Other Budget Entities

Table 1F. Voluntary Support of Higher Education

PERSONNEL

Table 2A. Personnel Headcount

\section{ENROLLMENT}

Table 3A. Headcount Enrollment by Student Type

Table 3B. Full-time Equivalent (FTE) Enrollment

Table 3C. Enrollment by Method of Instruction

Table 3D. Headcount Enrollment by Military Status and Student Level

Table 3E. University Access Rate: Undergraduate Enrollment with Pell Grant

\section{UNDERGRADUATE EDUCATION}

Table 4A. Baccalaureate Degree Program Changes in AY 2014-2015

Table 4B. Retention Rates

Table 4C. First-Time-in-College (FTIC) Six-Year Graduation Rates (Full-time only)

Table 4D. FTIC Graduation Rates (Full- and Part-time)

Table 4E. AA Transfers Graduation Rates

Table 4F. Other Transfers Graduation Rates

Table 4G. Baccalaureate Degrees Awarded

Table 4H. Baccalaureate Degrees Awarded in Areas of Strategic Emphasis

Table 4I. Baccalaureate Degrees Awarded to Underrepresented Groups

Table 4J. Baccalaureate Degrees Without Excess Credit Hours

Table 4K. Undergraduate Course Offerings

Table 4L. Faculty Teaching Undergraduates

Table 4M. Student/Faculty Ratio

Table 4N. Licensure/Certification Exam: Nursing

Table 4O. Post-Graduation Metrics

\section{GRADUATE EDUCATION}

Table 5A. Graduate Degree Program Changes in AY 2014-2015

Table 5B. Graduate Degrees Awarded

Table 5C. Graduate Degrees Awarded in Areas of Strategic Emphasis

Table 5D. Licensure/Certification Exams: Graduate Programs

\section{RESEARCH \& ECONOMIC DEVELOPMENT}

Table 6A. Research and Development Expenditures

Table 6B. Centers of Excellence 


\section{Section 1 - Financial Resources}

TABLE 1A. University Education and General Revenues

\begin{tabular}{lrrrrr} 
& $\begin{array}{r}\mathbf{2 0 1 1 - 1 2} \\
\text { Actual }\end{array}$ & $\begin{array}{r}\mathbf{2 0 1 2 - 1 3} \\
\text { Actual }\end{array}$ & $\begin{array}{r}\mathbf{2 0 1 3 - 1 4} \\
\text { Actual }\end{array}$ & $\begin{array}{r}\mathbf{2 0 1 4 - 1 5} \\
\text { Actual }\end{array}$ & $\begin{array}{r}\mathbf{2 0 1 5 - 1 6} \\
\text { Estimates }\end{array}$ \\
\hline MAIN OPERATIONS & & & & & \\
\hline Recurring State Funds & $\$ 11,296,196$ & $\$ 11,109,190$ & $\$ 12,393,930$ & $\$ 13,874,110$ & $\$ 14,341,394$ \\
\hline Non-Recurring State Funds & $\$ 123,086$ & $-\$ 993,867$ & $\$ 882,604$ & $\$ 200,000$ & $\$ 1,528,769$ \\
\hline Tuition & $\$ 5,991,659$ & $\$ 6,082,277$ & $\$ 6,293,560$ & $\$ 6,516,161$ & $\$ 7,499,918$ \\
\hline Tuition Differential Fee & $\$ 847,655$ & $\$ 1,397,116$ & $\$ 1,372,963$ & $\$ 1,419,335$ & $\$ 1,366,399$ \\
\hline Misc. Fees \& Fines & $\$ 63,259$ & $\$ 61,389$ & $\$ 70,589$ & $\$ 105,180$ & $\$ 133,320$ \\
\hline Phosphate Research TF & $\$ 0$ & $\$ 0$ & $\$ 0$ & $\$ 0$ & $\$ 0$ \\
\hline Federal Stimulus Funds & $\$ 0$ & $\$ 0$ & $\$ 0$ & $\$ 0$ & $\$ 0$ \\
\hline SUBTOTAL & $\$ 18,321,855$ & $\$ 17,656,105$ & $\$ 21,013,646$ & $\$ 22,114,786$ & $\$ 24,869,800$ \\
\multicolumn{1}{c}{ TOTAL } & $\$ 18,321,855$ & $\$ 17,656,105$ & $\$ 21,013,646$ & $\$ 22,114,786$ & $\$ 24,869,800$
\end{tabular}

Recurring State Funds: include general revenue and lottery education \& general (E\&G) appropriations and any administered funds provided by the state, including annual adjustments of risk management insurance premiums for the estimated year. This does not include technical adjustments or transfers made by universities after the appropriation. Please note: 2013-14 revenues include the non-recurring $\$ 300 \mathrm{M}$ system budget reduction. Sources: SUS Final Amendment Packages were used for actual years; and, the Allocation Summary and Workpapers were used for the estimated year. Non-Recurring State Funds: include general revenue and lottery education \& general appropriations and any administered funds provided by the state. This does not include technical adjustments or transfers made by Universities after the appropriation. Source: non-recurring appropriations section of the annual Allocation Summary and Workpapers that include all other non-recurring budget amendments allocated later in the fiscal year. Note on Performance Funding: the State investment piece of performance funding is reported in the 'Non-Recurring State Funds' and the Institutional investment piece is reported within 'Recurring State Funds'. Tuition: Actual resident \& non-resident tuition revenues collected from students, net of fee waivers. Source: Operating Budget, Report 625 Schedule I-A. Tuition Differential Fee: Actual tuition differential revenues collected from undergraduate students. Source: Operating Budget, Report 625 Schedule I-A. Miscellaneous Fees \& Fines: Other revenue collections include items such as application fees, late registration fees, library fines, miscellaneous revenues. This is the total revenue from Report 625 minus tuition and tuition differential fee revenues. This does not include local fees. Source: Operating Budget, Report 625 - Schedule I-A. Phosphate Research Trust Fund: State appropriation for the Florida Industrial and Phosphate Research Institute at the University of South Florida (for history years through 2012-13); beginning 2013-14 the Phosphate Research Trust Fund is appropriated through Florida Polytechnic University. Other Operating Trust Funds. For UF-IFAS and UF-HSC, actual revenues from the Incidental Trust Funds and Operations \& Maintenance Trust Fund are provided by the University of Florida. Source: Final Amendment Package. Federal Stimulus Funds: Non-recurring American Recovery and Reinvestment Act funds appropriated by the state. Source: SUS Final Amendment Package. This data is not adjusted for inflation. 


\section{Section 1 - Financial Resources (continued)}

\section{TABLE 1B. University Education and General Expenditures}

\begin{tabular}{lrrrrr} 
& $\mathbf{2 0 1 0 - 1 1}^{*}$ & $\mathbf{2 0 1 1 - 1 2}^{*}$ & $\mathbf{2 0 1 2 - 1 3}$ & $\mathbf{2 0 1 3 - 1 4}$ & $\mathbf{2 0 1 4 - 1 5}$ \\
\hline MAIN OPERATIONS & & & & & \\
\hline Instruction/Research & $\$ 9,995,147$ & $\$ 9,923,115$ & $\$ 11,126,818$ & $\$ 12,313,236$ & $\$ 13,472,997$ \\
\hline Administration and Support & $\$ 2,526,918$ & $\$ 2,196,199$ & $\$ 3,241,243$ & $\$ 3,425,543$ & $\$ 4,496,669$ \\
\hline PO\&M & $\$ 1,331,348$ & $\$ 1,135,491$ & $\$ 1,071,460$ & $\$ 1,127,601$ & $\$ 1,202,826$ \\
\hline Student Services & $\$ 1,859,587$ & $\$ 1,848,275$ & $\$ 1,582,750$ & $\$ 1,614,831$ & $\$ 1,737,160$ \\
\hline Library/Audio Visual & $\$ 363,719$ & $\$ 1,071,269$ & $\$ 1,102,445$ & $\$ 1,188,945$ & $\$ 1,181,901$ \\
Other & $\$ 0$ & $\$ 0$ & $\$ 0$ & $\$ 0$ & $\$ 0$ \\
TOTAL & $\$ 16,076,719$ & $\$ 16,174,349$ & $\$ \mathbf{1 8 , 1 2 4 , 7 1 6}$ & $\mathbf{\$ 1 9 , 6 7 0 , 1 5 6}$ & $\mathbf{\$ 2 2 , 0 0 9 1 , 5 5 3}$
\end{tabular}

The table reports the actual and estimated amount of expenditures from revenues appropriated by the legislature for each fiscal year. The expenditures are classified by Program Component (e.g., Instruction/Research, PO\&M, Administration, etc...) for activities directly related to instruction, research and public service. The table does not include expenditures classified as non-operating expenditures (e.g., to service asset-related debts), and therefore excludes a small portion of the amount appropriated each year by the legislature. Note*: FY 2012-2013 reflects a change in reporting expenditures from prior years due to the new carry-forward reporting requirement as reflected in the 2013-2014 SUS Operating Budget Reports. Since these expenditures will now include carry-forward expenditures, these data are no longer comparable to the current-year revenues reported in table $1 \mathrm{~A}$, or prior year expenditures in table 1B. This data is not adjusted for inflation.

Instruction \& Research: Includes expenditures for state services related to the instructional delivery system for advanced and professional education. Includes functions such as; all activities related to credit instruction that may be applied toward a postsecondary degree or certificate; non-project research and service performed to maintain professional effectives; individual or project research; academic computing support; academic source or curriculum development. Source: Operating Budget Summary - Expenditures by Program Activity (or Report 645). Administration \& Support Services: Expenditures related to the executive direction and leadership for university operations and those internal management services which assist and support the delivery of academic programs. Source: Operating Budget Summary - Expenditures by Program Activity (or Report 645). P0\&M: Plant Operations \& Maintenance expenditures related to the cleaning and maintenance of existing grounds, the providing of utility services, and the planning and design of future plant expansion and modification. Student Services: Includes resources related to physical, psychological, and social well-being of the student. Includes student service administration, social and cultural development, counseling and career guidance, financial aid, and student admissions and records. Other: includes Institutes and Research Centers, Radio/TV, Museums and Galleries, Intercollegiate Athletics, Academic Infrastructure Support Organizations. Source: Operating Budget Summary - Expenditures by Program Activity (or Report 645). 


\section{Section 1 - Financial Resources (continued)}

TABLE 1C. Funding per Full-Time Equivalent (FTE) Student

\begin{tabular}{lccccc} 
& $\mathbf{2 0 1 0 - 1 1}$ & $\mathbf{2 0 1 1 - 1 2}$ & $\mathbf{2 0 1 2 - 1 3}$ & $\mathbf{2 0 1 3 - 1 4}$ & $\mathbf{2 0 1 4 - 1 5}$ \\
\hline State Appropriation (GR \& Lottery) & $\$ 7,499$ & $\$ 7,133$ & $\$ 6,398$ & $\$ 8,571$ & $\$ 8,813$ \\
Tuition \& Fees (State-funded Aid) & $\$ 545$ & $\$ 481$ & $\$ 384$ & $\$ 527$ & $\$ 512$ \\
Tuition \& Fees (from Student) & $\$ 3,422$ & $\$ 3,831$ & $\$ 4,386$ & $\$ 4,468$ & $\$ 4,523$ \\
Other Trust Funds & $\$ 606$ & $\$ 0$ & $\$ 0$ & $\$ 0$ & $\$ 0$ \\
\hline TOTAL & $\$ 12,072$ & $\$ 11,444$ & $\$ 11,168$ & $\$ 13,566$ & $\$ 13,848$
\end{tabular}

Notes: State Appropriations includes General Revenues and Lottery funds that are directly appropriated to the university as reported in Final Amendment Package. This does not include appropriations for special units (e.g., IFAS, Health Science Centers, and Medical Schools). Tuition and Fee revenues include tuition and tuition differential fee and E\&G fees (e.g., application, late registration, and library fees/fines) as reported on the from the Operating Budget 625 reports. Other local fees that do not support E\&G activities are not included here (see Board of Governors Regulation 7.003). To more accurately report the full contribution from the State, this table reports the state-funded financial aid separately from the tuition and fee payments universities receive from students (which may include federal financial aid dollars). The state-funded gift aid includes grants and scholarships as reported by universities to Board during the academic year in the State University Database (SUDS). Other Trust funds (e.g., Federal Stimulus for 2009-10 and 2010-11 only) as reported in Final Amendment Package. Full-time Equivalent enrollment is based on actual FTE, not funded FTE; and, does not include Health-Science Center funds or FTE. This data is based on the standard IPEDS definition of FTE, equal to 30 credit hours for undergraduates and 24 for graduates. This data is not adjusted for inflation.

\section{TABLE 1D. Cost per Degree (Full Expenditures per Bachelor's Degree)}

2007-11

TOTAL
2008-12

2009-13

2010-14

2011-15

Reported at the USF System Level

Notes: Full expenditures include direct instructional, research and public service expenditures and the undergraduate portion of indirect expenditures (e.g., academic administration, academic advising, student services, libraries, university support, and Plant Operations and Maintenance). For each year, the full expenditures were divided by undergraduate fundable student credit hours to calculate the full expenditures per credit hour, and then multiplied by 30 credit hours to represent the annual undergraduate expenditures. The annual undergraduate expenditures for each of the four years was summed to provide an average undergraduate expenditures per (120 credit) degree. Source: State University Database System (SUDS), Expenditure Analysis: Report IV. This data is not adjusted for inflation. 


\section{Section 1 - Financial Resources (continued)}

TABLE 1E. University Other Budget Entities

2010-11 2011-12

2012-13

2013-14

2014-15

\section{Auxiliary Enterprises}

Revenues

n/a $\$ 1,888,702$

$\$ 1,859,520$

$\$ 1,989,594$

$\$ 2,272,898$

Expenditures

n/a $\$ 1,452,865$

$\$ 1,144,646$

$\$ 2,117,132$

$\$ 2,106,864$

Contracts \& Grants

\begin{tabular}{lrrrrr}
$\begin{array}{l}\text { Revenues } \\
\text { Expenditures } \\
\text { ocal Funds }\end{array}$ & $\mathrm{n} / \mathrm{a}$ & $\$ 207,283$ & $\$ 38,107$ & $-\$ 47,820$ & $\$ 168,148$ \\
$\mathrm{n} / \mathrm{a}$ & $\$ 300,044$ & $\$ 152,204$ & $\$ 246,905$ & $\$ 461,764$ \\
\hline $\begin{array}{l}\text { Revenues } \\
\text { Expenditures }\end{array}$ & $\mathrm{n} / \mathrm{a}$ & $\$ 1,149,499$ & $\$ 1,149,481$ & $\$ 1,129,900$ & $\$ 1,204,897$ \\
& $\mathrm{n} / \mathrm{a}$ & $\$ 576,226$ & $\$ 1,060,747$ & $\$ 909,324$ & $\$ 711,547$
\end{tabular}

Notes: Revenues do not include transfers. Expenditures do not include non-operating expenditures. Auxiliary Enterprises are self-supported through fees, payments and charges. Examples include housing, food services, bookstores, parking services, health centers. Contract \& Grants resources are received from federal, state or private sources for the purposes of conducting research and public service activities. Local Funds are associated with student activity (supported by the student activity fee), student financial aid, concessions, intercollegiate athletics, technology fee, green fee, and student life \& services fee. Faculty Practice Plan revenues/receipts are funds generated from faculty practice plan activities. Faculty Practice Plan expenditures include all expenditures relating to the faculty practice plans, including transfers between other funds and/or entities. This may result in double counting in information presented within the annual report. Source: Operating Budget, Report 615. This data is not adjusted for inflation. 


\section{Section 2 - Personnel}

\section{TABLE 2A. Personnel Headcount (in Fall term only)}

\begin{tabular}{lccccc} 
& $\mathbf{2 0 1 0}$ & $\mathbf{2 0 1 1}$ & $\mathbf{2 0 1 2}$ & $\mathbf{2 0 1 3}$ & $\mathbf{2 0 1 4}$ \\
\hline Full-time Employees & 13 & 13 & 14 & 17 & 23 \\
\hline Tenured Faculty & 19 & 24 & 21 & 14 & 14 \\
Tenure-track Faculty & 17 & 20 & 22 & 39 & 43 \\
Non-Tenure Track Faculty & 0 & 0 & 0 & 0 & 0 \\
Instructors Without Faculty Status & 0 & 0 & 0 & 0 & 0 \\
Graduate Assistants/Associates & 101 & 95 & 93 & 102 & 112 \\
Non-Instructional Employees & $\mathbf{1 5 0}$ & $\mathbf{1 5 2}$ & $\mathbf{1 5 0}$ & $\mathbf{1 7 2}$ & $\mathbf{1 9 2}$ \\
\hline FULL-TIME SUBTOTAL & & & & & \\
Part-time Employees & 1 & 1 & 0 & 0 & 0 \\
\hline Tenured Faculty & 0 & 0 & 0 & 0 & 0 \\
Tenure-track Faculty & 86 & 75 & 64 & 74 & $57^{*}$ \\
Non-Tenure Track Faculty & 0 & 0 & 0 & 0 & $0^{*}$ \\
Instructors Without Faculty Status & 4 & 5 & 7 & 4 & 5 \\
Graduate Assistants/Associates & 0 & 0 & 0 & 0 & 0 \\
Non-Instructional Employees & $\mathbf{9 1}$ & $\mathbf{8 1}$ & $\mathbf{7 1}$ & $\mathbf{7 8}$ & $\mathbf{6 2}$ \\
\hline PART-TIME SUBTOTAL & & & & & $\mathbf{2 5}$ \\
\hline \multicolumn{1}{c}{ TOTAL } & $\mathbf{2 4 1}$ & $\mathbf{2 3 3}$ & $\mathbf{2 2 1}$ & $\mathbf{2 5 0}$ & $\mathbf{2 5}$
\end{tabular}

Note: This table is based on the annual IPEDS Human Resources Survey, and provides full- and part-time medical and non-medical staff by faculty status and primary function/occupational activity. Tenured and Tenure-Track Faculty include those categorized within instruction, research, or public service. Non-Tenure Track Faculty includes adjunct faculty (on annual and less than annual contracts) and faculty on multi-year contracts categorized within instruction, research, or public service. Instructors Without Faculty Status includes postdoctoral research associates, and individuals hired as a staff member primarily to do research on a 3-year contract without tenure eligibility categorized within instruction, research, or public service. Non-Instructional Employees includes all executive, administrative and managerial positions regardless of faculty status; as well as, other support and service positions regardless of faculty status. Note: The universities vary on how they classify adjuncts (some include them as non-tenure track faculty while others do not consider them faculty and report them as instructors without faculty status) and part-time non-instructional employees. 


\section{Section 3 - Enrollment}

TABLE 3A. Headcount Enrollment by Student Type and Level

\begin{tabular}{cccccc} 
& Fall 2010 & Fall 2011 & Fall 2012 & Fall 2013 & Fall 2014 \\
\hline TOTAL & 1,897 & 1,919 & 1,952 & 1,887 & 1,917
\end{tabular}

\section{UNDERGRADUATE}

\begin{tabular}{lccccc}
\hline FTIC (Regular Admit) & 26 & 27 & 30 & 109 & 195 \\
FTIC (Profile Admit) & & & & & 1 \\
AA Transfers & 1,052 & 1,117 & 1,099 & 995 & 944 \\
Other Transfers & 455 & 461 & 582 & 567 & 400 \\
\hline Subtotal & $\mathbf{1 , 5 3 3}$ & $\mathbf{1 , 6 0 5}$ & $\mathbf{1 , 7 1 1}$ & $\mathbf{1 , 6 7 1}$ & $\mathbf{1 , 5 4 0}$
\end{tabular}

GRADUATE

\begin{tabular}{lccccc}
\hline Master's & 184 & 159 & 140 & 128 & 120 \\
Research Doctoral & 0 & 0 & 0 & 0 & 0 \\
Professional Doctoral & 0 & 0 & 0 & 0 & 0 \\
Dentistry & 0 & 0 & 0 & 0 & 0 \\
Law & 0 & 0 & 0 & 0 & 0 \\
Medicine & 0 & 0 & 0 & 0 & 0 \\
Nursing Practice & 0 & 0 & 0 & 0 & 0 \\
Pharmacy & 0 & 0 & 0 & 0 & 0 \\
Physical Therapist & 0 & 0 & 0 & 0 & 0 \\
Veterinary Medicine & 0 & 0 & 0 & 0 & 0 \\
Other & 0 & 0 & 0 & 0 & 0 \\
\hline Subtotal & 184 & 159 & 140 & 128 & 120
\end{tabular}

UNCLASSIFIED

\begin{tabular}{lccccc}
\hline HS Dual Enrolled & 0 & 0 & 0 & 0 & 0 \\
Other & 180 & 155 & 101 & 88 & 257 \\
\hline Subtotal & $\mathbf{1 8 0}$ & $\mathbf{1 5 5}$ & $\mathbf{1 0 1}$ & $\mathbf{8 8}$ & $\mathbf{2 5 7}$
\end{tabular}

Note: This table reports the number of students enrolled at the university by student type categories. The determination for undergraduate, graduate and unclassified is based on the institutional class level values. Unclassified refers to a student who has not yet been formally admitted into a degree program but is enrolled. The student type for undergraduates is based on the Type of Student at Time of Most Recent Admission. The student type for graduates is based on the degree that is sought and the student CIP code. Students classified by the university as post-baccalaureate are counted as "other" unclassified for the purposes of this table. This differs from the methodology used to produce data for the online interactive enrollment tool (on the Board's website), which includes post-bacs as undergraduates regardless of degree sought. 


\section{Section 3 - Enrollment (continued)}

TABLE 3B. Full-Time Equivalent (FTE) Enrollment [State Fundable only]

2012-13

State-

Funded
2013-14

State-

Actual
2014-15

\begin{tabular}{lcccccc} 
& $\begin{array}{c}\text { State- } \\
\text { Funded }\end{array}$ & Actual & $\begin{array}{c}\text { State- } \\
\text { Funded }\end{array}$ & Actual & $\begin{array}{c}\text { State- } \\
\text { Funded }\end{array}$ & Actual \\
\hline FLORIDA RESIDENTS & \multicolumn{7}{l}{} & \multicolumn{1}{l}{} \\
\hline Lower-Division & 0 & 133 & 0 & 205 &. & 254 \\
Upper-Division & 798 & 931 & 798 & 821 &. & 804 \\
Master's (GRAD I) & 182 & 92 & 182 & 92 &. & 86 \\
Doctoral (GRAD II) & 0 & 0 & 0 & 0 &. & 0 \\
\hline Subtotal & 980 & $\mathbf{1 , 1 5 6}$ & $\mathbf{9 8 0}$ & $\mathbf{1 , 1 1 9}$ &. & $\mathbf{1 , 1 4 4}$
\end{tabular}

NON-FLORIDA RESIDENTS

\begin{tabular}{llc|cc|cc}
\hline Lower-Division & $\cdot$ & 8 & $\cdot$ & 12 &. & 17 \\
Upper-Division &. & 19 & $\cdot$ & 25 &. & 31 \\
Master's (GRAD I) & $\cdot$ & 6 & $\cdot$ & 5 &. & 6 \\
Doctoral (GRAD II) &. & 0 &. & 0 &. & 0 \\
\hline Subtotal & $\mathbf{0}$ & $\mathbf{3 3}$ & $\mathbf{0}$ & $\mathbf{4 3}$ &. & $\mathbf{5 3}$
\end{tabular}

\section{TOTAL FTE}

\begin{tabular}{lcc|cc|cc}
\hline Lower-Division & 0 & 141 & 0 & 217 & 0 & 271 \\
Upper-Division & 798 & 950 & 798 & 847 & 798 & 835 \\
Master's (GRAD I) & 182 & 97 & 182 & 98 & 182 & 91 \\
Doctoral (GRAD II) & 0 & 0 & 0 & 0 & 0 & 0 \\
\hline Total & $\mathbf{9 8 0}$ & $\mathbf{1 , 1 8 9}$ & $\mathbf{9 8 0}$ & $\mathbf{1 , 1 6 2}$ & $\mathbf{9 8 0}$ & $\mathbf{1 , 1 9 8}$ \\
\hline Total (US Definition) & $\mathbf{1 , 3 0 7}$ & $\mathbf{1 , 5 8 1}$ & $\mathbf{1 , 3 0 7}$ & $\mathbf{1 , 5 4 9}$ & $\mathbf{1 , 3 0 7}$ & $\mathbf{1 , 5 9 6}$ \\
\hline
\end{tabular}

Notes: Full-time Equivalent (FTE) student is a measure of instructional effort (and student activity) that is based on the number of credit hours that students enroll by course level. FTE is based on the Florida definition, which divides undergraduate credit hours by 40 and graduate credit hours by 32 (US definition based on Undergraduate FTE $=30$ and Graduate FTE = 24 credit hours). In 2013-14, the Florida Legislature chose to no longer separate funded non-resident FTE from funded resident FTE. Funded enrollment as reported in the General Appropriations Act and Board of Governors' Allocation Summary. Actual enrollment only reports 'state-fundable' FTE as reported by Universities to the Board of Governors in the Student Instruction File (SIF). Totals are actual and may not equal sum of reported student levels due to rounding of student level FTE. Total FTE are equal in tables $3 \mathrm{~B}$ and $3 \mathrm{C}$.

Data provided by USF 


\section{Section 3 - Enrollment (continued)}

\section{TABLE 3C. Full-Time Equivalent (FTE) Enrollment by Method of Instruction} 2010-11 2011-12 2012-13 2013-14 2014-15

\section{TRADITIONAL}

$\begin{array}{lrrrrr}\text { Lower-Division } & 41 & 63 & 65 & 129 & 171 \\ \text { Upper-Division } & 536 & 503 & 459 & 360 & 364 \\ \text { Master's (GRAD 1) } & 100 & 86 & 72 & 71 & 57 \\ \text { Doctoral (GRAD 2) } & 0 & 1 & 0 & 0 & 0 \\ \text { TOTAL } & 677 & \mathbf{6 5 3} & \mathbf{5 9 7} & \mathbf{5 6 0} & \mathbf{5 9 2}\end{array}$

\section{HYBRID}

$\begin{array}{lrrrrr}\text { Lower-Division } & 0 & 3 & 7 & 8 & 8 \\ \text { Upper-Division } & 27 & 31 & 26 & 37 & 17 \\ \text { Master's (GRAD 1) } & 3 & 4 & 4 & 4 & 4 \\ \text { Doctoral (GRAD 2) } & 0 & 0 & 0 & 0 & 0 \\ \text { TOTAL } & \mathbf{3 0} & \mathbf{3 8} & \mathbf{3 7} & \mathbf{5 0} & \mathbf{2 9}\end{array}$

\section{DISTANCE LEARNING}

$\begin{array}{lrrrrr}\text { Lower-Division } & 25 & 44 & 69 & 80 & 91 \\ \text { Upper-Division } & 442 & 446 & 465 & 449 & 455 \\ \text { Master's (GRAD 1) } & 22 & 20 & 22 & 22 & 30 \\ \text { Doctoral (GRAD 2) } & 1 & 0 & 0 & 0 & 0 \\ \text { TOTAL } & 490 & \mathbf{5 1 0} & \mathbf{5 5 5} & \mathbf{5 5 1} & \mathbf{5 7 7}\end{array}$

\section{TOTAL}

$\begin{array}{lrrrrr}\text { Lower-Division } & 66 & 110 & 141 & 217 & 271 \\ \text { Upper-Division } & 1,005 & 980 & 950 & 847 & 835 \\ \text { Master's (GRAD 1) } & 125 & 110 & 97 & 98 & 91 \\ \text { Doctoral (GRAD 2) } & 1 & 1 & 0 & 0 & 0 \\ \text { TOTAL } & 1,197 & \mathbf{1 , 2 0 1} & \mathbf{1 , 1 8 9} & \mathbf{1 , 1 6 2} & \mathbf{1 , 1 9 8}\end{array}$

Note: Full-time Equivalent (FTE) student is a measure of instructional effort (and student activity) that is based on the number of credit hours that students enroll by course level. FTE is based on the Florida definition, which divides undergraduate credit hours by 40 and graduate credit hours by 32. Distance Learning is a course in which at least 80 percent of the direct instruction of the course is delivered using some form of technology when the student and instructor are separated by time or space, or both (per 1009.24(17), F.S.). Hybrid is a course where 50\% to $79 \%$ of the instruction is delivered using some form of technology, when the student and instructor are separated by time or space, or both (per SUDS data element 2052). Traditional (and Technology Enhanced) refers to primarily face to face instruction utilizing some form of technology for delivery of supplemental course materials for no more than $49 \%$ of instruction (per SUDS data element 2052). Totals are actual and may not equal sum of reported student levels due to rounding of student level FTE. Total FTE are equal in tables $3 \mathrm{~B}$ and $3 \mathrm{C}$.

Data provided by USF 


\section{Section 3 - Enrollment (continued)}

TABLE 3D. Headcount Enrollment by Military Status and Student Level

Fall $2010 \quad$ Fall $2011 \quad$ Fall $2012 \quad$ Fall $2013 \quad$ Fall 2014

\begin{tabular}{lccccc}
\hline MILITARY & \multicolumn{1}{c}{ ( } & & & \\
\hline Unclassified & 1 & 4 & 1 & 0 & 1 \\
Undergraduate & 3 & 5 & 8 & 69 & 75 \\
Master's (GRAD 1) & 0 & 0 & 0 & 6 & 3 \\
Doctoral (GRAD 2) & 56 & 52 & 60 & 75 & 79 \\
Subtotal & & & & & \\
DEPENDENTS & 0 & 0 & 0 & 0 & 0 \\
\hline Unclassified & 9 & 10 & 14 & 9 & 7 \\
Undergraduate & 1 & 0 & 1 & 1 & 0 \\
Master's (GRAD 1) & 0 & 0 & 0 & 0 & 0 \\
Doctoral (GRAD 2) & 10 & 10 & 15 & 10 & 7 \\
Subtotal & 179 & 151 & 99 & 88 & 104 \\
NON-MILITARY & 1,472 & 1,552 & 1,647 & 1,593 & 1,610 \\
\hline Unclassified & 180 & 154 & 131 & 121 & 117 \\
Undergraduate & 0 & 0 & 0 & 0 & 0 \\
Master's (GRAD 1) & 1,831 & 1,857 & 1,877 & 1,802 & 1,831 \\
Doctoral (GRAD 2) & 1,897 & 1,919 & 1,952 & 1,887 & 1,917 \\
Subtotal & & & & & \\
\hline TOTAL & & & & & \\
\hline
\end{tabular}

Note: This table provides trend data on the number of students enrolled based on their military status. Military includes students who were classified as Active Duty, Veterans, National Guard, or Reservist.. Eligible Dependents includes students who were classified as eligible dependents (dependents who received veteran's benefits). Non-Military includes all other students.

\section{TABLE 3E. University Access Rate: Undergraduate Enrollment with Pell Grant}

\begin{tabular}{lccccc} 
& Fall 2010 & Fall 2011 & Fall 2012 & Fall 2013 & Fall 2014 \\
\hline Pell Grant Recipients & 687 & 793 & 711 & 679 & 690 \\
\hline Percent with Pell Grant & $45.32 \%$ & $49.84 \%$ & $41.65 \%$ & $40.73 \%$ & $40.97 \%$
\end{tabular}

Note: This table reports the University's Access Rate, which is a measure of the percentage of undergraduate students who have received a federal Pell grant award during a given Fall term. The top row reports the number of students who received a Pell Grant award. The bottom row provides the percentage of eligible students that received a Pell Grant award. This metric was included in the Board of Governors Performance Based Funding Model in 2014 - for more information see: http://www.flbog.edu/about/budget/performance_funding.php. 


\section{Section 4 - Undergraduate Education}

\section{TABLE 4A. Baccalaureate Degree Program Changes in AY 2014-15}

\begin{tabular}{|l|l|l|l|l|l|}
\hline \multicolumn{1}{|c|}{ Title of Program } & $\begin{array}{c}\text { Six-digit } \\
\text { CIP } \\
\text { Code }\end{array}$ & \multicolumn{1}{|c|}{$\begin{array}{c}\text { Degree } \\
\text { Level }\end{array}$} & $\begin{array}{c}\text { Date of } \\
\text { UBOT } \\
\text { Action }\end{array}$ & $\begin{array}{c}\text { Starting } \\
\text { or Ending } \\
\text { Term }\end{array}$ & Comments \\
\hline New Programs & & & & & \\
\hline none & & & & & \\
\hline & & & & \\
\hline Terminated Programs & & & & \\
\hline none & & & & \\
\hline & & & & \\
\hline Programs Suspended for New Enrollments & & & \\
\hline none & & & & \\
\hline & & & \\
\hline New Programs Considered By University But Not Approved & & \\
\hline none &
\end{tabular}

Note: This table does not include new majors or concentrations added under an existing degree program CIP Code. This table reports the new and terminated program changes based on Board action dates between May 5, 2014 and May 4, 2015.

New Programs are proposed new degree programs that have been completely through the approval process at the university and, if appropriate, the Board of Governors. Does not include new majors or concentrations added under an existing degree program CIP Code.

Terminated Programs are degree programs for which the entire CIP Code has been terminated and removed from the university's inventory of degree programs. Does not include majors or concentrations terminated under an existing degree program CIP Code if the code is to remain active on the academic degree inventory.

Programs Suspended for New Enrollments are degree programs for which enrollments have been temporarily suspended for the entire CIP Code, but the program CIP Code has not been terminated. Does not include majors or concentrations suspended under an existing degree program CIP Code if the code is to remain active on the academic degree inventory and new enrollments in any active major will be reported. Programs included in this list may have been suspended for new enrollments sometime in the past and have continued to be suspended at least one term of this academic year.

New Programs Considered by University But Not Approved includes any programs considered by the university board of trustees, or any committee of the board, but not approved for implementation. Also include any programs that were returned prior to board consideration by the university administration for additional development, significant revisions, or re-conceptualization; regardless of whether the proposal was eventually taken to the university board for approval. Count the returns once per program, not multiple times the proposal was returned for revisions, unless there is a total re-conceptualization that brings forward a substantially different program in a different CIP Code. 


\section{Section 4 - Undergraduate Education (continued)}

\section{TABLE 4B. Full-time, First-Time-in-College (FTIC) Retention Rates Retained in the Second Fall Term at Same University}

2010-11

Cohort Size
2011-12
2013-14

83 with Any GPA

with GPA 2.0 or higher

Retained within USF-System

with Any GPA

with GPA 2.0 or higher
$79 \%$

$\begin{array}{cc}72 \% & 79 \% \\ 69.88 \% & 78.65 \%\end{array}$

$81 \%$

$87 \%$

$77.11 \%$
Retained at USF-Sar.-Man.

西

Notes: Cohorts are based on undergraduate students who enter the institution in the Fall term (or Summer term and continue into the Fall term). Percent Retained with Any GPA is based on student enrollment in the Fall term following their first year. Percent Retained with GPA Above 2.0 is based on student enrollment in the Fall term following their first years for those students with a GPA of 2.0 or higher at the end of their first year (Fall, Spring, Summer). The most recent year of Retention data is based on preliminary data (SIFP file) that is comparable to the final data (SIF file) but may be revised in the following years based on changes in student cohorts.

\section{TABLE 4C. Full-time, First-Time-in-College (FTIC) Six-Year Graduation Rates}

Term of Entry

Cohort Size

$\%$ Graduated

\% Still Enrolled

\% Success Rate
USF-SM began admitting FTICs in Fall 2013. 


\section{Section 4 - Undergraduate Education (continued)}

\section{TABLE 4E. Graduation Rates for AA Transfer Students from Florida College System}

\begin{tabular}{cccccc} 
Two - Year Rates & $\mathbf{2 0 0 9 - 1 1}$ & $\mathbf{2 0 1 0 - 1 2}$ & $\mathbf{2 0 1 1 - 1 3}$ & $\mathbf{2 0 1 2 - 1 4}$ & $\mathbf{2 0 1 3 - 1 5}$ \\
\hline Cohort Size & 223 & 278 & 253 & 243 & 222 \\
Same University & $\mathbf{3 0 \%}$ & $\mathbf{2 9} \%$ & $\mathbf{3 4 \%}$ & $\mathbf{2 5 \%}$ & $\mathbf{2 2 \%}$
\end{tabular}

\begin{tabular}{cccccc} 
Four - Year Rates & $\mathbf{2 0 0 7 - 1 1}$ & $\mathbf{2 0 0 8 - 1 2}$ & $\mathbf{2 0 0 9 - 1 3}$ & $\mathbf{2 0 1 0 - 1 4}$ & $\mathbf{2 0 1 1 - 1 5}$ \\
\hline Cohort Size & 231 & 272 & 223 & 278 & 253 \\
Same University & $\mathbf{5 7 \%}$ & $\mathbf{5 3 \%}$ & $\mathbf{6 5 \%}$ & $\mathbf{6 3 \%}$ & $\mathbf{6 0 \%}$
\end{tabular}

Notes: AA Transfer cohort is defined as undergraduates entering in the fall term (or summer continuing to fall) and having earned an AA degree from an institution in the Florida College System. For comparability with FTIC cohorts, AA Transfer cohorts are based on undergraduate students who enter the institution in the Fall term (or Summer term and continue into the Fall term) and graduate from the same institution within two or four years.

\section{TABLE 4F. Graduation Rates for Other Transfer Students}

\begin{tabular}{cccccc}
$\mathbf{5 - Y e a r}$ Rates & $\mathbf{2 0 0 6 - 1 1}$ & $\mathbf{2 0 0 7 - 1 2}$ & $\mathbf{2 0 0 8 - 1 3}$ & $\mathbf{2 0 0 9 - 1 4}$ & $\mathbf{2 0 1 0 - 1 5}$ \\
\hline Cohort Size & 173 & 191 & 149 & 191 & 199 \\
Same University & $\mathbf{5 7 \%}$ & $\mathbf{5 4 \%}$ & $\mathbf{5 6} \%$ & $\mathbf{6 1 \%}$ & $\mathbf{6 0 \%}$
\end{tabular}

Notes: Other Transfer Students includes undergraduate students that transfer into a university who are not FTICs or AA Transfers. Cohorts are based on undergraduate students who enter the institution in the Fall term (or Summer term and continue into the Fall term) and graduate from the same institution within five years. 


\section{Section 4 - Undergraduate Education (continued)}

TABLE 4G. Baccalaureate Degrees Awarded

\begin{tabular}{lccccc} 
& $\mathbf{2 0 1 0 - 1 1}$ & $\mathbf{2 0 1 1 - 1 2}$ & $\mathbf{2 0 1 2 - 1 3}$ & $\mathbf{2 0 1 3 - 1 4}$ & $\mathbf{2 0 1 4 - 1 5}$ \\
\hline First Majors & 453 & 514 & 556 & 490 & 474 \\
Second Majors & 2 & 7 & 5 & 2 & 3 \\
\hline TOTAL & 455 & 521 & 561 & 492 & 477
\end{tabular}

Note: This table reports the number of degrees awarded by academic year. First Majors include the most common scenario of one student earning one degree in one Classification of Instructional Programs (CIP) code. In those cases where a student earns a baccalaureate degree under two different degree CIPs, a distinction is made between "dual degrees" and "dual majors." Also included in first majors are "dual degrees" which are counted as separate degrees (e.g., counted twice). In these cases, both degree CIPs receive a "degree fraction" of 1.0. Second Majors include all dual/second majors (e.g., degree CIP receive a degree fraction that is less than 1). The calculation of degree fractions is made according to each institution's criteria. The calculation for the number of second majors rounds each degree CIP's fraction of a degree up to 1 and then sums the total. Second Majors are typically used when providing degree information by discipline/CIP, to better conveys the number of graduates who have specific skill sets associated with each discipline.

\section{TABLE 4H. Baccalaureate Degrees in Programs of Strategic Emphasis (PSE)} [Includes Second Majors]

2010-11

STEM

HEALTH

GLOBALIZATION

EDUCATION

GAP ANALYSIS

SUBTOTAL

14

0

0

96

66

176

$38.68 \%$

PSE PERCENT OF TOTAL
2011-12 2012-13

2013-14

21

20

48

75

0

0

63

58

0

40

2014-15

35

54

0

28

79

196

Notes: This is a count of baccalaureate majors for specific Programs of Strategic Emphasis, as determined by the Board of Governors staff with consultation with business and industry groups and input from universities. This is a count of baccalaureate degrees awarded within specific Programs of Strategic Emphasis, as determined by the Board of Governors staff with consultation with business and industry groups and input from universities - for more information see: http://www.flbog.edu/pressroom/strategic_emphasis/. The Board of Governors revised the list of Programs of Strategic Emphasis in November 2013, and the new categories were applied to the historical degrees. A student who has multiple majors in the subset of targeted Classification of Instruction Program codes will be counted twice (i.e., double-majors are included). 


\section{Section 4 - Undergraduate Education (continued)}

TABLE 4I. Baccalaureate Degrees Awarded to Underrepresented Groups

2010-11 2011-12 2012-13 2013-14 2014-15

Non-Hispanic Black

$\begin{array}{llllll}\text { Number of Degrees } & 22 & 24 & 35 & 16 & 36 \\ \text { Percentage of Degrees } & 5 \% & 5 \% & 6 \% & 3 \% & 8 \%\end{array}$

Hispanic

$\begin{array}{lccccc}\text { Number of Degrees } & 35 & 58 & 65 & 59 & 71 \\ \text { Percentage of Degrees } & 8 \% & 12 \% & 12 \% & 12 \% & 15 \%\end{array}$

Pell-Grant Recipients

$\begin{array}{llllll}\text { Number of Degrees } & 219 & 284 & 309 & 267 & 255 \\ \text { Percentage of Degrees } & 49 \% & 55 \% & 56 \% & 55 \% & 54 \%\end{array}$

Note: Non-Hispanic Black and Hispanic do not include students classified as Non-Resident Alien or students with a missing race code. Students who earn two distinct degrees in the same term are counted twice - whether their degrees are from the same six-digit CIP code or different CIP codes. Students who earn only one degree are counted once - even if they completed multiple majors or tracks. Percentage of Degrees is based on the number of baccalaureate degrees awarded to non-Hispanic Black and Hispanic students divided by the total degrees awarded - excluding those awarded to non-resident aliens and unreported.

Pell-Grant recipients are defined as those students who have received a Pell grant from any SUS Institution within six years of graduation - excluding those awarded to non-resident aliens, who are only eligible for Pell grants in special circumstances. Percentage of Degrees is based on the number of baccalaureate degrees awarded to Pell recipients, as shown above, divided by the total degrees awarded - excluding those awarded to non-resident aliens.

Notes on Trends: In 2007, the US Department of Education re-classified the taxonomy for self-reported race/ethnicity categories and allowed universities a two-year phase-in process before all institutions were required to report based on the new categories for the 2011-12 academic year. This reclassification will impact trends. 


\section{Section 4 - Undergraduate Education (continued)} TABLE 4J. Baccalaureate Degrees Without Excess Credit Hours

\begin{tabular}{|c|c|c|c|c|c|}
\hline & $2010-11^{*}$ & $2011-12^{*}$ & $2012-13^{* *}$ & $2013-14^{* *}$ & 2014-15 \\
\hline FTIC & \multirow{4}{*}{$\begin{array}{l}\text {-Data reported at } \\
\text { the System } \\
\text { Level }\end{array}$} & $64 \%$ & . & . & $54 \%$ \\
\hline AA Transfers & & $68 \%$ & $73 \%$ & $81 \%$ & $82 \%$ \\
\hline Other Transfers & & $46 \%$ & $69 \%$ & $67 \%$ & $58 \%$ \\
\hline TOTAL & & $60 \%$ & $71 \%$ & $75 \%$ & $72 \%$ \\
\hline
\end{tabular}

Notes: This table is based on statute 1009.286 (see link), and excludes certain types of student credits (e.g., accelerated mechanisms, remedial coursework, non-native credit hours that are not used toward the degree, non-native credit hours from failed, incomplete, withdrawn, or repeated courses, credit hours from internship programs, credit hours up to 10 foreign language credit hours for transfer students in Florida, and credit hours earned in military science courses that are part of the Reserve Officers' Training Corps (ROTC) program). This metric is not the same as the Excess Hours Surcharge, which has multiple cohorts with varying fee rates. This table reports the percentage of baccalaureate degrees awarded within $110 \%$ of the catalog hours required for a degree based on the Board of Governors Academic Program Inventory. This calculation is based on Hours To Degree data submitted by universities to the Board of Governors and excludes recent graduates who have already earned a baccalaureate degree. Note*: Improvements were made to data collection process beginning with 2012-13 data to better account for high school dual enrolled credits that are exempt from the excess hour calculation. Note $^{* *}$ : To protect the privacy of educational records of university students, data for cohort counts 10 or less are not reported.

\section{TABLE 4K. Undergraduate Course Offerings}

\begin{tabular}{lccccc} 
& Fall 2010 & Fall 2011 & Fall 2012 & Fall 2013 & Fall 2014 \\
\hline $\begin{array}{c}\text { Number of } \\
\text { Course Sections }\end{array}$ & 129 & 135 & 127 & 135 & 160 \\
$\begin{array}{l}\text { Percentage of Undergraduate } \\
\text { Pewer than 30 Students }\end{array}$ & $84 \%$ & $77 \%$ & $81 \%$ & $85 \%$ & $83 \%$ \\
\hline 30 to 49 Students & $12 \%$ & $20 \%$ & $15 \%$ & $11 \%$ & $16 \%$ \\
\hline 50 to 99 Students & $3 \%$ & $2 \%$ & $3 \%$ & $4 \%$ & $2 \%$ \\
\hline 100 or More Students & $0 \%$ & $1 \%$ & $1 \%$ & $0 \%$ & $0 \%$
\end{tabular}

Notes: This data is based on Common Data Set (CDS) definitions. According to CDS, a "class section is an organized course offered for credit, identified by discipline and number, meeting at a stated time or times in a classroom or similar setting, and not a subsection such as a laboratory or discussion session. Undergraduate class sections are defined as any sections in which at least one degree-seeking undergraduate student is enrolled for credit. Exclude distance learning classes and noncredit classes and individual instruction such as dissertation or thesis research, music instruction, or one-to-one readings. Exclude students in independent study, co-operative programs, internships, foreign language taped tutor sessions, practicums, and all students in one-on-one classes. 


\section{Section 4 - Undergraduate Education (continued)}

TABLE 4L. Percentage of Undergraduate Credit Hours Taught by Instructor Type

\begin{tabular}{lccccc} 
& $\mathbf{2 0 1 0 - 1 1}$ & $\mathbf{2 0 1 1 - 1 2}$ & $\mathbf{2 0 1 2 - 1 3}$ & $\mathbf{2 0 1 3 - 1 4}$ & $\mathbf{2 0 1 4 - 1 5}$ \\
\hline Faculty & $64 \%$ & $65 \%$ & $62 \%$ & $63 \%$ & $62 \%$ \\
\hline Adjunct Faculty & $34 \%$ & $34 \%$ & $37 \%$ & $36 \%$ & $34 \%$ \\
\hline Graduate Students & $1 \%$ & $0 \%$ & $1 \%$ & $0 \%$ & $1 \%$ \\
\hline Other Instructors & $1 \%$ & $1 \%$ & $0 \%$ & $1 \%$ & $3 \%$
\end{tabular}

Note: The total number of undergraduate state fundable credit hours taught will be divided by the undergraduate credit hours taught by each instructor type to create a distribution of the percentage taught by each instructor type. Four instructor types are defined as faculty (pay plans 01,02 , and 22), OPS faculty (pay plan 06), graduate student instructors (pay plan 05), and others (all other pay plans). If a course has more than one instructor, then the university's reported allocation of section effort will determine the allocation of the course's total credit hours to each instructor. The definition of faculty varies for Tables $4 \mathrm{~L}, 4 \mathrm{M}$ and $4 \mathrm{~N}$. For Faculty Teaching Undergraduates, the definition of faculty is based on pay plans 01,02 , and 22.

\section{TABLE 4M. Student/Faculty Ratio}

Fall 2010

\section{Ratio} 15
Fall 2011 15
Fall 2012 15
Fall 2013 13
Fall 2014 13

Note: This data is based on Common Data Set (CDS) definitions. This is the Fall ratio of full-time equivalent students (full-time plus $1 / 3$ part time) to full-time equivalent instructional faculty (full time plus $1 / 3$ part time). The ratio calculations exclude both faculty and students in stand-alone graduate or professional programs such as medicine, law, veterinary, dentistry, social work, business, or public health in which faculty teach virtually only graduate-level students. Undergraduate or graduate student teaching assistants are not counted as faculty. 


\section{Section 4 - Undergraduate Education (continued)}

\section{TABLE 40. Post-Graduation Metrics}

\section{Percent of Bachelor's Graduates Employed Full-time or Continuing their Education, One Year After Graduation}

\begin{tabular}{lcccc} 
& $\mathbf{2 0 1 0 - 1 1}$ & $\mathbf{2 0 1 1 - 1 2}$ & $\mathbf{2 0 1 2 - 1 3}$ & $\mathbf{2 0 1 3 - 1 4}$ \\
\hline Enrolled or Employed (Full-time) & $70.72 \%$ & $71.85 \%$ & $75.81 \%$ & $72.73 \%$ \\
Enrolled or Employed (Earned \$25,000+) &. &. & $65.52 \%$ & $62.81 \%$ \\
Number of States included in Search & 1 & 36 & 38 & 38 \\
Percent Found & $91 \%$ & $89 \%$ & $92 \%$ & $92 \%$
\end{tabular}

Notes: Enrolled or Employed Full-Time is based on the number of recent baccalaureate graduates who are either employed full-time or continuing their education within one year after graduation. Full-time employment is based on those who earned at least as much as a full-time (40hrs a week) worker making minimum wage. Enrolled or Employed (Earning \$25,000+) is based on the number of recent baccalaureate graduates who are either employed and earned at least $\$ 25,000$ or continuing their education within one year after graduation. The employed data includes non-Florida data that is available from the Wage Record Interchange System 2 (known as "WRIS 2") and Federal employee data that is available from the Federal Employment Data Exchange System (FEDES) initiative. Military employment data was collected by the Board of Governors staff from university staff. Due to limitations in the data, the continuing enrollment data includes any enrollment the following year regardless of whether the enrollment was post-baccalaureate or not. Percent Found refers to the percentage of graduates found in the dataset - including those that did not earn wages above the full-time threshold and those who were found outside of the one-year window.

For more information about the methodology see: http://www.flbog.edu/about/budget/performance_funding.php.

For more information about WRIS2 see: $h$ htp://www.doleta.gov/performance/wris 2.cfm.

For more information about FEDES see: http://www.ubalt.edu/fif/fedes/.

Median Wages of Bachelor's Graduates Employed Full-time in Florida, One Year After Graduation

\begin{tabular}{lcccc} 
& $\mathbf{2 0 1 0 - 1 1}$ & $\mathbf{2 0 1 1 - 1 2}$ & $\mathbf{2 0 1 2 - 1 3}$ & $\mathbf{2 0 1 3 - 1 4}$ \\
\hline 5th PERCENTILE WAGE & $\$ 16,400$ & $\$ 18,100$ & $\$ 18,200$ & $\$ 18,800$ \\
\hline 25th PERCENTILE WAGE & $\$ 25,300$ & $\$ 25,800$ & $\$ 26,000$ & $\$ 27,200$ \\
\hline MEDIAN WAGE & $\mathbf{\$ 3 3 , 6 0 0}$ & $\mathbf{\$ 3 3 , 2 0 0}$ & $\mathbf{\$ 3 6 , 0 0 0}$ & $\mathbf{\$ 3 5 , 6 0 0}$ \\
\hline 75th PERCENTILE WAGE & $\$ 44,100$ & $\$ 41,300$ & $\$ 46,700$ & $\$ 44,600$ \\
\hline 95th PERCENTILE WAGE & $\$ 62,000$ & $\$ 62,700$ & $\$ 64,500$ & $\$ 67,900$ \\
\hline Percent Found & $61 \%$ & $62 \%$ & $62 \%$ & $58 \%$
\end{tabular}

Notes: Median Wage data is based on Florida's annualized Unemployment Insurance (UI) wage data for those graduates who earned at least as much as a full-time employee making minimum wage in the fiscal quarter a full year after graduation. This $\mathrm{UI}$ wage data does not include individuals who are selfemployed, employed out of state, employed by the military or federal government, or those without a valid social security number. This wage data includes graduates who were both employed and enrolled. Wages rounded to nearest hundreds. Percent Found refers to the percentage of graduates found in the dataset - including those that did not earn wages above the full-time threshold and those who were found outside of the one-year window. 


\section{Section 5 - Graduate Education}

\section{TABLE 5A. Graduate Degree Program Changes in AY 2014-15}

\begin{tabular}{|l|l|l|l|l|l|l|}
\hline \multicolumn{1}{|c|}{ Title of Program } & $\begin{array}{c}\text { Six-digit } \\
\text { CIP } \\
\text { Code }\end{array}$ & $\begin{array}{c}\text { Degree } \\
\text { Level }\end{array}$ & $\begin{array}{c}\text { Date of } \\
\text { UBOT } \\
\text { Action }\end{array}$ & $\begin{array}{c}\text { Starting } \\
\text { or Ending } \\
\text { Term }\end{array}$ & $\begin{array}{c}\text { Date of } \\
\text { Board of } \\
\text { Governors } \\
\text { Action }\end{array}$ & Comments \\
\hline New Programs & & & & & & \\
\hline None & & & & & \\
\hline & & & & & \\
\hline Terminated Programs & & & & & \\
\hline None & & & & & \\
\hline & & & & & \\
\hline \\
\hline
\end{tabular}

Note: This table does not include new majors or concentrations added under an existing degree program CIP Code. This table reports the new and terminated program changes based on Board action dates between May 5, 2014 and May 4, 2015.

New Programs are proposed new degree programs that have been completely through the approval process at the university and, if appropriate, the Board of Governors. Does not include new majors or concentrations added under an existing degree program CIP Code.

Terminated Programs are degree programs for which the entire CIP Code has been terminated and removed from the university's inventory of degree programs. Does not include majors or concentrations terminated under an existing degree program CIP Code if the code is to remain active on the academic degree inventory.

Programs Suspended for New Enrollments are degree programs for which enrollments have been temporarily suspended for the entire CIP Code, but the program CIP Code has not been terminated. Does not include majors or concentrations suspended under an existing degree program CIP Code if the code is to remain active on the academic degree inventory and new enrollments in any active major will be reported. Programs included in this list may have been suspended for new enrollments sometime in the past and have continued to be suspended at least one term of this academic year.

New Programs Considered by University But Not Approved includes any programs considered by the university board of trustees, or any committee of the board, but not approved for implementation. Also include any programs that were returned prior to board consideration by the university administration for additional development, significant revisions, or re-conceptualization; regardless of whether the proposal was eventually taken to the university board for approval. Count the returns once per program, not multiple times the proposal was returned for revisions, unless there is a total re-conceptualization that brings forward a substantially different program in a different CIP Code. 
Section 5 - Graduate Education (continued)

TABLE 5B. Graduate Degrees Awarded

\begin{tabular}{lccccc} 
& $\mathbf{2 0 1 0 - 1 1}$ & $\mathbf{2 0 1 1 - 1 2}$ & $\mathbf{2 0 1 2 - 1 3}$ & $\mathbf{2 0 1 3 - 1 4}$ & $\mathbf{2 0 1 4 - 1 5}$ \\
\hline First Majors & 68 & 72 & 60 & 55 & 50 \\
Second majors & 0 & 0 & 0 & 0 & 0 \\
\hline TOTAL & $\mathbf{6 8}$ & $\mathbf{7 2}$ & $\mathbf{6 0}$ & $\mathbf{5 5}$ & $\mathbf{5 0}$ \\
\hline Masters and Specialist (first majors) & 68 & 72 & 60 & 55 & 50 \\
Research Doctoral (first majors) & 0 & 0 & 0 & 0 & 0 \\
Professional Doctoral (first majors) & 0 & 0 & 0 & 0 & 0 \\
\hline Dentistry & 0 & 0 & 0 & 0 & 0 \\
Law & 0 & 0 & 0 & 0 & 0 \\
Medicine & 0 & 0 & 0 & 0 & 0 \\
\hline Nursing Practice & 0 & 0 & 0 & 0 & 0 \\
Pharmacy & 0 & 0 & 0 & 0 & 0 \\
Physical Therapist & 0 & 0 & 0 & 0 & 0 \\
\hline Veterinary Medicine & 0 & 0 & 0 & 0 & 0 \\
Other Professional Doctorate & 0 & 0 & 0 & 0 & 0
\end{tabular}

Note: This table reports the total number of graduate level degrees that were awarded by academic year as well as the number by level. The table provides a breakout for the Professional Doctoral degrees.

TABLE 5C. Graduate Degrees Awarded in Areas of Strategic Emphasis [Includes Second Majors]

2010-11

2011-12

2012-13

2013-14

2014-15

\begin{tabular}{|c|c|c|c|c|c|}
\hline STEM & 0 & 0 & 0 & 0 & 0 \\
\hline HEALTH & 3 & 0 & 0 & 0 & 0 \\
\hline GLOBALIZATION & 0 & 0 & 0 & 0 & 0 \\
\hline EDUCATION & 29 & 31 & 18 & 15 & 6 \\
\hline GAP ANALYSIS & 0 & 0 & 0 & 0 & 0 \\
\hline SUBTOTAL & 32 & 31 & 18 & 15 & 6 \\
\hline PSE PERCENT OF TOTAL & $47.06 \%$ & $43.06 \%$ & $30.00 \%$ & $27.27 \%$ & $12.00 \%$ \\
\hline \multicolumn{6}{|c|}{$\begin{array}{l}\text { Notes: This is a count of graduate degrees awarded within specific Areas of Strategic Emphasis, as determined by the Board of Governors staff with } \\
\text { consultation with business and industry groups and input from universities. This is a count of graduate degrees awarded within specific Programs of } \\
\text { Strategic Emphasis, as determined by the Board of Governors staff with consultation with business and industry groups and input from universities - for } \\
\text { more information see: http://www.flbog.edu/pressroom/strategic emphasis/. The Board of Governors revised the list of Programs of Strategic Emphasis } \\
\text { in November 2013, and the new categories were applied to the historical degrees. A student who has multiple majors in the subset of targeted } \\
\text { Classification of Instruction Program codes will be counted twice (i.e., double-majors are included). Note: The denominator used in the percentage } \\
\text { includes second majors. }\end{array}$} \\
\hline
\end{tabular}




\section{Section 6 - Research and Economic Development} TABLE 6A. Research and Development

2009-10

2010-11

2011-12

2012-13

2013-14

\section{R\&D Expenditures}

Total (S\&E and non-S\&E)

(\$1,000s)

Federally Funded

(\$1,000s)

Percent Funded

From External Sources

Total R\&D Expenditures

Per Full-Time, Tenured,

Tenure-Earning Faculty Member (\$)

$\$ 23,610$

$\$ 28,560$

$\$ 21,190$

$\$ 29,740$

$\$ 33,100$

Notes: R\&D Expenditures are based on the National Science Foundation's annual Survey of R\&D Expenditures at Universities and Colleges (data include Science \& Engineering and non-Science \& Engineering awards). Percent Funded from External Sources is defined as funds from federal, private industry and other sources (non-state and non-institutional funds). Total R\&D expenditures are divided by fall, full-time tenured/tenure-track faculty as reported to IPEDS (FGCU includes both tenured/tenure-track and non-tenure/track faculty). The fall faculty year used will align with the beginning of the fiscal year (e.g., 2007 FY R\&D expenditures are divided by fall 2006 faculty). Invention Disclosures reports the number of disclosures made to the university's Office of Technology Commercialization to evaluate new technology - as reported on the Association of University Technology Managers Annual (AUTM) annual Licensing Survey. Licenses \& Options Executed that were executed in the year indicated for all technologies - as reported by AUTM. Licensing Income Received refers to license issue fees, payments under options, annual minimums, running royalties, termination payments, amount of equity received when cashed-in, and software and biological material end-user license fees of $\$ 1,000$ or more, but not research funding, patent expense reimbursement, valuation of equity not cashed-in, software and biological material end-user license fees of less than $\$ 1,000$, or trademark licensing royalties from university insignia - as reported on the AUTM survey. Number of Start-up Companies that were dependent upon the licensing of University technology for initiation - as reported on the Association of University Technology Managers Annual Licensing Survey. REVISED: US Patents Issued awarded by the United States Patent and Trademark Office (USPTO) by Calendar year. 